\title{
本誌口絵「酒醸一式の図」の 連載にあたって
}

\section{古市 明 紀}

埼玉県岩㭇市の鈴木酒造(姝)資料館に明治初めの造 り酒屋の店の場面から清酒の出荷の場面までのパネル 写真が展示してある。

原画は次の十六枚となっているが

\begin{tabular}{|c|c|}
\hline 一番＼cjkstart見勢之部 & 二番 米買入之部 \\
\hline 三番 米揚之部 & 四番 廣敷之部 \\
\hline 五番 米洗之部 & 釜屋之部 \\
\hline 七番 竹流之部 & 糀室之部 \\
\hline 九番 酛仕込之部 & 十番 酛スリ之部 \\
\hline 十一番 仕込之部 & 十二番 揚糟之部 \\
\hline 十三番 澱引之部 & 十四番 焼酎取之部 \\
\hline 十五番 火入之部 & 十六番 荷出之部 \\
\hline
\end{tabular}
損がみられる。

これらの絵は, 浮世絵芸術が円熟期に達し歌舞伎や 庶民の日常生活が，自然に描かれ親しまれた時期の作 風であり，芸術品としても，また，明治初期の酒造り を知る上でも極めて貴重な絵であるだけに久損, 破損 部分がいかにも悔やまれる。

今月号から，十五枚の絵について連載して解説する こととしたい。

\section{絵 の 由 来}

鈴木家が酒造りを始めたのは, 明治 4 年である。こ の頃は岩梘・本宿の関根という大地主の蔵を借りて酒 造りを行っていた。この絵はこの蔵における酒造りを 描いたものである。なお，鈴木家は明治 15 年に現在 地に移転している。

鈴木家の初代当主, 芳兵衛（現在の当主は 5 代目） が明治 14 年頃群馬県草津へ湯治に行ったおり，おな しく湯治に来ていた浮世絵師豊原國周に合い, 懇意と なり，酒造りの密画（細かい描写で精密に対象を描い た絵）を成田山の不動様に奉納するために書いてもら ったのがこの絵である。

國周は約一力月間鈴木家に滞在し, 毎日ご馳走で遊
び遊び仕事をし,200円の報酬をもらったという。当時， 上等酒が十一銭，中等酒で八銭くらいであったから， 今のお金に換算すると五百万円くらいであろうか。

絵は明治十五年頃, $15 \mathrm{~cm}$ 位の枠の木造額縁に格子 状にして奉納されていたが, 痛みがひどく, 最近はが して別々に洗濯, 裏打ちして成田山新勝寺の資料館の 倉庫に保存されている。

この絵は, 埼玉県博物館が絵馬展を開いたおり，新 勝寺から絵を借りて写したものを複写したものである。

なお, 絵の制作年を明治 14 年としたのは, 國周が 鈴木家から帰る前に書いたとされる初代芳兵衛の肖像 画（現在掛け軸となっている）に明治 14 年國周書の 署名があることによる。

\section{作者について}

豊原國周（1835.6.4.〜1900.7.1）は幕末から明治 にかけての浮世絵師である。本名荒川八十八, 別号鶯 斎, 一桃, 華蝶桜。江戸京橋で父大島九十郎, 母抢八 百の子として生まれ, 東京で没。14 歳で 3 代歌川豊 国の門に入り，初期には「安政見聞誌」(1855) 挿絵 があり, 幕末報道絵, 横浜絵ののち, 1869 年の具足 版役者大首絵によって知られる。

「開花人情報」(1878)，「潤色三十六歌撰」（1881）, 「現時五十四情」(1884)，「婦人束髪会」（1885）など の新旧美人画連作もあるが, 明治前半期には役者絵が 多く，江戸生き残り浮世絵師として長い活動歴を持つ。

また，その生涯において 117 回の引っ越しを行って おり, 北斎の 80 回余を上回る。

國周に関連する歌川派の系図は次のとうりである 歌川豊春一歌川豊国一一豊重 $(2$ 代豊国)

一国貞 (3 代豊国) 一國周 一国芳

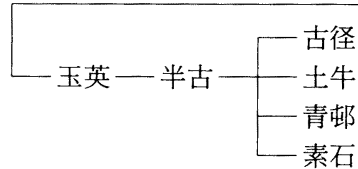


3 代豊国には弟子は多いが, 国周は師匠の豊国とは しっくりとした関係になかったために，伝統的な歌川 の姓ではなく豊原を名乗ったのではないかといわれて いる。しかし, 国周の何代か後の弟子に文化勲章を受 けた両家が目立つのもおもしろい。
参考 文 献
1）明治人物夜話
2）世界美術事典 新潮社

\section{執筆者紹介（順不同・敬称略）}

手島義春 $<$ Yoshiharu Teshima $>$

昭和 16 年 4 月 3 日生れ<勤務先とその所在地 $>$ 広 島県立食品工業技術センター, テ732-0816 広島市南 区比治山本町 $12-70<$ 略歴>昭和 36 年広島県立竹原 高等学校醇造科卒, 同年広島県立食品工業試験場西条 清酒醸造支場勤務, 同 49 年広島県食品工業試験場勤務, 同 59 年 4 月組織改正により広島県立食品工業技術七 ンターに改名, 平成 8 年 4 月醌酵食品部長, 現在に至 る。<抱負〉米を原料とした新しい酒を開発すること

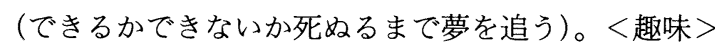
若い時は陸上部に入り, 無心に走ることによってスト レスを解消したが, 体力の限界で最近は卓球を楽しん でいる。雑種の犬が 3 年前に入りこみ, 乗り物が好き でドライブ, 及びトラクター, コンバイン等なんでも 乗り自分の命に従うので犬がすきになり犬と散歩して いる。

\section{土屋義信 $<$ Yoshinobu Tsuchiya $>$}

昭和 26 年 8 月 7 日生れ $<$ 勤務先とその所在地 $>$ 広 島県立食品工業技術センター, テ732-0816 広島市南 区比治山本町 $12-70<$ 略歴>昭和 57 年広島大学大学 院博士過程（後期）工学研究科醱酵工学専攻修了, 同 年広島県食品工業試験場勤務, 同 59 年 4 月組織改正 により広島県立食品工業技術センターに改称, 現在に 至る。<抱負>広島県の杜氏, 経営者の方々と一緒に 常により良い酒をめざして頑張っていきたい。く趣 味>音楽（主にJAZZ）鑑賞，最近は愛猫のお相手。

\section{木原 誠 $<$ Makoto KIHARA $>$}

昭和 41 年 1 月 31 日生れ<勤務先とその所在地 > サ ッポロビール(侏植物工学研究所, テ370-0393 群馬県 新田郡新田町木崎 37-1<略歴>昭和 63 年北海道大学 農学部農学科卒, 平成 2 年弘前大学大学院修士課程,
農学研究科修了, 同年サッポロビール(陎入社, 同社植 物工学研究所配属, 現在に至る。<抱負>地球の未来 を明るくする研究をしていきたい。く趣味〉スキー, ツーリング。

\section{久寿米木一裕 $<$ Kazuhiro KUSUMEGI $>$}

昭和 26 年 8 月 18 日生れ<勤務先とその所在地>ヤ マエ食品工業(株)，广885-0076 宮崎県都城市西町 $3646<$ 略歴>昭和 49 年宮崎大学農学部農業化学科卒, 同年ヤマエ食品工業(侏)入社, 現在に至る, 同 62 年技 術士 (農業部門, 農芸化学), 現在 研究開発課長< 抱負 > 醬油味噌等の醸造技術改善。風味について関心 を持ちたい。く趣味〉スポーツ観戦, 読書, 自然散策。

鮫島吉広 < Yoshihiro SAMESHIMA >

昭和 22 年 11 月 22 日生れ<勤務先とその所在地> 薩摩酒造(株), テ898-0025 鹿児島県枕崎市立神本町 26 番地 <略歷>昭和 46 年京都大学農学部食品工学科 卒, 同 46 年ニッカウイスキー(株) 入社, 同 51 年薩摩 酒造 (株) 入社, 同 52 年薩摩酒造 (株) 研究室長, 平成 3 年薩摩酒造 (株) 常務取締役製造部長兼研究所長。 く抱負>焼酎あるいはサツマイモを通して, 世界がど こまで広がるかに強い関心を持っている。く趣味>詩 吟。

中島雅毅 $<$ Masaki NAKASHIMA $>$

昭和 33 年 10 月 6 日生れ<勤務先とその所在地 $>$ 薩 摩酒造(株), テ $898-0025$ 鹿児島県枕崎市立神本町 26 番地 $<$ 略歷 $>$ 昭和 57 年東京農業大学農学部醸造学科 卒, 同年薩摩酒造 (株) 研究所所属。現在に至る。<抱 負>様々な酒を味わうこと, また愛すること。く趣 味>釣り全般, 年相応の釣りを楽しんでいきたい。今 は磯釣りがメイン。 